UDC 351.74

DOI https://doi.org/10.32844/2618-1258.2019.1-1.28

KUZMENKO I.G.

\title{
TOPICAL ISSUES OF THE SCIENTIFIC ORGANIZATION OF MANAGERIAL LABOR AT THE NATIONAL POLICE OF UKRAINE (ORGANIZATIONAL AND LEGAL ASPECT)
}

An analytical review of the scientific management of management work in the activities of the National Police of Ukraine and the police of the EU countries has been carried out. Particular attention is paid to the scientific organization of managerial labor and the professional training of senior management of police systems. The quality of managerial influence on the object of management, which depends on the organization of the activity of the subjects of management of all levels and units, is determined. The contents of the concepts of the scientific organization of labor and the scientific organization of management labor, the components of which they determine and the difference between them is revealed. In the paper, the analysis revealed a lack of organization of work to increase its rationalization through the introduction of changes that include scientific and technological progress and good practice. The task of the economic, psychological and social nature of the scientific organization of labor, which is represented in a single organic system, is substantiated. The issue is related to the study of foreign experience in the organization of business activities in developed countries, which allows some generalizing conclusions about the features of management of police systems that have a long history, extensive experience in the fight against crime and public order protection. A characteristic feature of the police activity of the developed countries is the high social and legal security of the police officer. Material security prompts him to properly fulfill his functional responsibilities, professional growth that affects the human resources of the police. Based on the study of labor and police experience in the Federal Republic of Germany, France, Austria, Switzerland, the United States, the United Kingdom, Spain and other countries, general conclusions are drawn about the specifics of the management of foreign police systems. Conducted conclusions about European experience in training police guards.

Key words: police, police activity, scientific organization of labor, scientific organization of managerial labor, EU countries, use of police experience.

Здійснено аналітичний огляд наукової організації управлінської праці в діяльності Національної поліції України та поліції країн ЄС. Особлива увага приділена науковій організації управлінської праці та професійній підготовці вищого керівного складу поліцейських систем. Визначено якість управлінського впливу на об'єкт управління, що залежить від організації діяльності суб'єктів управління усіх рівнів і ланок. Розкрито зміст понять «наукова організація праці» та «наукова організація управлінської праці», складники, що їх зумовлюють, та відмінність між ними. У роботі шляхом аналізу виявлено недостатність організації праці до все більшої іiі раціоналізації за допомогою внесення змін, що містять науково-технічний прогрес і передова практика. Обгрунтовано завдання економічного, психологічного та соціального характеру наукової організації праці, які представлено в єдину органічну систему. Висвітлено питання пов'язане з вивченням зарубіжного досвіду організації службової діяльності розвинутих країн світу, що дозволяє зробити деякі узагальнюючі висновки про особливості управління поліцейськими системами, які мають довготривалу історію, великий досвід боротьби зі злочинністю й охорони публічного порядку. Характерною особливістю діяльності поліції розвинутих країн $є$ висока соціальна та правова безпека співробітника поліції. Матеріальна безпека спонукає його належним чином виконувати свої функціональні обов'язки, професійне зростання, що впливає на людські ресурси поліції.

(C) KUZMENKO I.G. - Postgraduate Student at the Department of Public Administration and Administration (National Academy of Internal Affairs) 
На основі вивчення досвіду організації праці та поліцейської діяльності у Федеративній Республіці Німеччина, Франції, Австрії, Швейцарії, Сполучених Штатах Америки, Великій Британії та Іспанії. Сформовано висновки щодо європейського досвіду підготовки керівних кадрів поліції.

Ключові слова: полічія, полічейська діяльність, наукова організачія прачі, наукова організачія управлінської праці, краӥни ЄС, використання досвіду поліції.

Introduction. Management is a complex socio-political and eco-nomic process of the subject' s influence on management objects in order to ensure stability or transfer from one state to another according to defined goals. The main task of managerial activity is to find the performers with the necessary skills and qualification development, to combine them into commonly agreed actions, to define the general goals for them, for the achievement of which they have the appropriate rights and responsibilities, to create a rational organizational structure and to provide its activities with the necessary technical and legal conditions. Management requires a clear organization that can not be effective without an effective legal basis and the achievement of a modern scientific approach. To manage effectively, it is not necessary first of all to organize the work of the person who is engaged in managerial activity, that is, the subject of management. The quality of the managerial influence on the object of management depends on how organized the activities of the subjects of management are. Consequently, the scientific management organization directly concerns employees of management structures of all levels and units.

Setting of the scientific problem. The purpose of the article is to study topical issues of the scientific organization of managerial labor at the national police of ukraine in organizational and legal aspects.

Definition of research objectives. The management of the National Police in modern conditions requires the training of managers of professionals who use their strategy and tactics of management, the principles and methods of working with the staff, the basics of operative arts, sociology and logic, psychology and pedagogy, focusing on complex political, economic, technical and other issues, possess modern organizational and managerial technologies.

The complication in the modern period of the content of management activities in the field of law and order and crime control causes increased requirements for the training of highly qualified managers capable of solving new and more complex administrative tasks. It is in our opinion that it is possible to solve some key issues in this process with the help of the Scientific Organization of Managerial Labor (SOML).

As you know, any labor process represents the unity of three factors: own labor (living labor or man), labor and tools. To use rationally, on the one hand, the living labor, and on the other - the essential elements of the labor process, that is, tools and objects of labor, requires the organization of labor, which would provide a combination of labor with tools and objects to achieve a specific production goal $[1, \mathrm{c} .639]$. Only this should be borne in mind that the problem of the organization of work relates not only to the sphere of material production, but also to the sphere of management, in particular, to the sphere of activity of the bodies of the National Police.

For example, when it comes to the sphere of material production, and we are dealing with, say, a worker-machine tool, then the three factors of labor are difficult to identify: 1) the employee himself; 2) tools - a machine tool; 3) item of work - a part.

In the social sphere, namely in the labor process, the police, for example, the inspector of the staff unit of the National Police, can be identified as follows: 1) inspectors (as labor); 2) tools - methods of processing information (in this category of management personnel - operational) and appropriate technical means used to extract, process and save information; 3 ) the subject of labor is the information itself. The organic combination of these components is carried out in the labor process, which creates a product of labor. For a worker-worker, the product of labor will be a detail, and for the headquarters inspector - any summary, analytical statement, forecast of a particular situation, and ultimately - a draft management decision (order, etc.).

With the help of the Scientific Organization of Labor (SOL), tasks of economic, psychological and social nature are fulfilled. All of them are in organic unity; among them there are no main and secondary ones.

The economic objectives of the SOL are to achieve a high level of labor productivity through the intensive use of live labor and material elements of production.

The psychophysiological tasks of the SOL are to provide the most favorable conditions for normal functioning, reproduction of the expended effort, preservation of health and efficiency of workers.

The social tasks of the SOL include the creation of conditions for the continuous growth of the professional and cultural level of workers, the comprehensive and harmonious development of them, the transformation of labor into the first vital human need [1, p. 641]. 
In order to combine social labor with its tools and subject, it is not enough to have them available; here the organizational preconditions are needed, which include: mastering the technician and appropriate methods and methods of information processing; creating a workplace and working conditions. In addition, since it is about social work, humanity is interested in the economical use of all resources, high quality of work and its productivity. Organizational preconditions are also needed for the realization of these social needs: norms for the use of resources; observance of the discipline of labor; forms of its distribution and co-operation in the team; incentives for creative activity, etc.

The implementation of the organizational preconditions through which human effort is combined with tools and objects of labor, the rational use of these components is the organization of work. Scientific it becomes when the organizational premise is the result of scientific development, and not only intuition, common sense and traditions [2, p. 110].

When using an SOL, the emergence of each organizational element is preceded by a thorough scientific analysis of labor processes and the conditions for their implementation. Consequently, the word "scientific" in relation to the concept of "organization of work" means that the resolution of its practical issues should be based not on subjective assessments, not on traditional methods and methods of work, but on the whole set of achievements of science, technology, technology and best practices , which provide the most rational and effective organization of labor processes. Thus, the path to the SOL lies through the normal organization of labor to increasingly rationalize it through the introduction of that new, containing scientific and technological progress and good practice. The SOL is the highest stage in the rational organization of work.

The scientific organization of labor is an integral part of the organizational management function. One of its peculiarities lies in the fact that it is always secondary in relation to the production (main) functions and control functions. Thus, when creating or improving one or another system, first of all, determined, specify its functions, and only then solve the problem of organization of labor the workers themselves, who perform these functions [2, p. 109].

The Scientific Labor Organization (SOL) - is such an organization in which the practical implementation of concrete measures is preceded by a thorough scientific analysis of the labor processes and the conditions for their implementation, and the practical measures themselves are based on the achievements of modern science and best practice. [1, p. 642]. However, this definition does not reflect the entire nature of the SOL, therefore, it should be considered as indicative. The difference between the concepts of "organization of work" and "scientific organization of labor" is determined by the approach to solving the same problems, the degree of scientific validity of specific decisions.

The word "scientific" in this case means that the resolution of the practical issues of the organization of work should be based not on subjective assessments and decisions, not on simple techniques and methods of work, but on the whole set of achievements of science and practice that provides the most rational, most effective organization of labor processes. Thus, the path to the SOL is through its usual organization to increasingly rationalizing through the introduction of the new, which is given to us by scientific and technological progress and good practice. The SOL - is like a higher stage of rational organization of labor [2, p. 109].

Organization of work and organization of management are in some way independent categories, but at the same time, and are closely interrelated. Moreover, if the management organization provides for the development and establishment of a clear system of governance, the most rational management structure, organization of analysis, planning, accounting and control over the process in general, etc., then the organization of labor relates only to the social work of people.

The variety of the SOL is the SOML (scientific organization of managerial labor), which has its own distinct parties. One of them is the object of influence. The object of the influence of the SOL - is physical labor, the object of the influence of SOML - is mental.

What is the difference between these notions of the SOL and the SOML? First and foremost, the basis of this heterogeneity are the two main groups of labor processes: labor processes, which are mainly associated with the cost of physical effort, and labor processes, mainly associated with the cost of mental effort. It belongs to the latter group of management work, since its main purpose and content is the activity to develop a variety of managerial decisions, or, in other words, management information. The work of the majority of National Police officers who develop and implement managerial decisions regarding the protection of public order and the fight against crime is no exception. Due to the fact that people who manage other people, themselves establish not only receptions, but, as a rule, tasks, and the results of their work are manifested in the original products (managerial decisions) [2, p. 110].

Scientific organization of managerial labor is nothing more than a scientific organization of mental labor. If the introduction of the SOL focuses on rationalizing physical efforts to increase the productivity of physical labor, the SOML has the task of rationalizing mental effort and thereby increasing the 
productivity of mental work. In other words, the improvements that are being made to the SOML should maximize the unloading of a person who operates information, develops and implements management decisions, from excessive physical and mental loads, and technical work, so that she retains as much time and effort as possible for creative activities.

Consequently, it is possible to define the concept of SOML as follows: the scientific organization of managerial labor - is a means of increasing the productivity of persons who operate information and make managerial decisions by introducing scientific methods in the field of rational use of working time, rationalization of labor operations, and also the creation of favorable working conditions. [1, c. 643].

The work of the National Police is very specific. First, police officers do not participate in the creation of material and spiritual values directly, but only provide direct workers with protection of their legitimate rights, personal and public security, thus creating favorable conditions for their labor processes; Secondly, work in the police authorities is largely mixed in terms of its division into managerial and production.

Indeed, unlike in the manufacturing sector, where these two types of labor are divided, in the bodies of the National Police, many categories of workers are engaged in both managerial and executive activities: they participate in the protection of public order, the investigation of offenders, the investigation of crimes, etc.

Crime, both in Ukraine and in developed countries of the world, is considered one of the social laws and is constantly in the focus of attention of state and political figures, lawyers, journalists, scientists and practitioners-specialists of the law-enforcement system. Causes and conditions of crime, measures to protect the law and order, protection of human rights and freedoms from criminal offenses are constantly considered at meetings of parliaments and government structures, are covered in mass media, are under the control of the public. Often, the fate of politicians, the success of political parties, and the stability of governments depend on their programs and concerted efforts in combating crime and adhering to the rule of law in the state.

The police systems of the developed countries of the world, especially such as France, Great Britain, the United States of America, Italy, Canada, Austria, Japan, the Federal Republic of Germany $[3$, p.28] have a long history, a great experience of combating crime and protection of public order, close interrelationships with each other. From the professional point of view, significant and interesting measures are taken to build modern police systems in the neighboring states that are closest to Ukraine, which have become independent in recent years, in particular, in Latvia, Lithuania, Moldova, and Slovakia $[10$, p. 87$]$.

The study of experience in the organization of work and policing in the Federal Republic of Germany, France, Austria, Switzerland, the United States of America, Great Britain, Spain, and other countries makes it possible to draw some general conclusions about the peculiarities of the management of foreign police systems, namely:

- ramification and diversity of police systems, the presence of police authorities in various ministries and departments, their independence among themselves;

- the police of the member states of the European Union are guided not only by national legislation, but also by normative acts adopted by the Union [3, p. 32];

- distribution of police systems by sources of financing to state (federal), municipal (local self-government), private (police companies, concerns, syndicates) in conditions of close cooperation between them;

- the social orientation of the work of the police, which protects, first of all, the rights and freedoms of a citizen held at the expense of taxes of the population and, accordingly, the functions of the police are that it serves as a kind of assistance to a citizen and for the commission of a crime, and in an accident, in an extreme situation, in a domestic conflict, what;

- high professionalism of the police; a police officer in the United States, Britain, France, and other countries is compelled to study throughout the service; this depends on his promotion, the assignment of an officer rank, remuneration, benefits, etc.;

- non-partisan in the work of the police; the police serve the people, the state, and not the parties;

Active activity of public voluntary associations, aimed at supporting and assisting the police;

Openness, publicity, constant appeal to the people's opinion in solving difficult situations arising in law-enforcement practice, provide police with trust and support of the population [4, p. 3-5].

Police take an active part in all activities conducted among the population, organize sports competitions, holidays, work in schools and pre-school establishments, carry out patronage work, report to the population and thus realize the idea of rapprochement with them. In the course of official training by the US, Federal Republic of Germany, France, Italy, a special course "Working with the population" is being studied. 
In political systems of foreign countries the departments of psychological, social work, connections with the population, public organizations, mass media are very important.

In the vast majority of European countries, in the United States and Japan, the Ministry of Internal Affairs focuses both on police services and state security services, which ensures close interaction between them and saves public funds [8, p. 180].

It should be noted separately that the use of scientific and technical means by the police of foreign countries is extremely widespread. The latest achievements of the natural sciences and engineering sciences are at the service of the police. The police have a ramified system of expert and research institutions. The laws of the United States, France, Great Britain, Canada, and the Federal Republic of Germany establish such a procedure for the use of scientific and technical means that promotes the identification of truth in the investigation of crimes and at the same time protects the rights and legitimate interests of citizens $[5$, p. 20]

Close cooperation between police systems through Interpol and directly between themselves (conferences, symposia, exchange of delegations, study of experience, training, joint policing activities in several countries). The special experience of the police of foreign countries has been acquired in the investigation of interstate crimes in the field of drug trafficking, "rubbing" money, concealing profits and tax evasion, unfair competition, bankruptcy, violations of laws on trademarks and rules of the Republican, environmental crimes and so on.

Conclusion. Almost all foreign police systems have the status of a civilian police service; employees can perform duties in the form or in civilian clothes, have the most advanced weapons. Police officers are subject to basic political and trade union rights, with the exception of the right to strike and engage in political activities. In all democratic countries, the police are non-partisan [9, p. 182-184].

A characteristic feature of the police activity of the developed countries is the high social and legal security of the police officer. Material security prompts him to properly fulfill his functional duties, professional growth, which affects the human resources of the police.

Of course, with some common features, each political system has its own national character, its own experience, its modern structure and forms of activity.

\section{References:}

1. Plikshykin V.N. Theory of management of internal affairs: under the leadership. / [ed. Yu. F. Kravchenko]. Kiev : NAVSU, 1999. 702 pp.

2. Petkov S.V. Scientific organization of managerial labor and rational use of managerial personnel - constituent elements of the implementation of the foundations of effective management of the Ministry of Internal Affairs of Ukraine-Kh., 2005. P. 108-111.

3. Konenko S.Ya. Reorganization of the system of the Ministry of Internal Affairs of Ukraine at the present stage of state formation: (from the experience of German police reorganization). Kiev : Knowledge of Ukraine, 2006. 44 p.

4. Negotchenko O.V. Use of experience of foreign police work to improve work with personnel of the Ministry of Internal Affairs for ensuring human rights and freedoms. Scientific Bulletin of the Dnipropetrovsk Academy of Law. Dnipropetrovsk, 2004. No. 1 (14). P. 3-13.

5. Zarosilov V.O. Comparative analysis of the administrative activity of the police of Ukraine and the police of foreign countries (Great Britain, USA, Canada and France): author's abstract. dis for obtaining sciences. Degree Candidate lawyer Sciences: special 12.00.07 "Administrative Law" / VO Enough. Kiev, 2002. 19 p.

6. Zaporozhtsev Ye.G. Improvement of the modern system of training the officer of the ATS in the light of foreign experience and the position of pedagogy / / South-Ukrainian Legal Journal. 2007. №1. C. 263-265.

7. Pronnevich O.S. The notion of "police" ("militia") in the administrative (police) right of modern states. University of Internal Affairs (KhNUVD). Herald. №3. X. 2011. C. 249-256.

8. Council of Europe Declaration "On Police" / The Political Dimension of the Ministry of Internal Affairs of Ukraine (Answer to the Challenges of the 21st Century) / Ed. Yu. I. Rymarenko, Yu. Yu. Kondratiev. Kiev : NAVSU, 2003. 292 p.

9. Gubanov A.V. Polity of foreign countries: Organizational-legal bases, strategy and tactics of activity. Moscow, 1999. 286 pp.

10. Drop O.M. Bodies of internal affairs of Ukraine in conditions of its integration into the EU: Dis. ... Candidate lawyer Sciences (12.00.07) / KNUU. Kyiv, 2007. 213 c. 